\title{
ISOLATION AND CHARACTERIZATION OF FUSARIUM OXYSPORUM F. SP. ALBEDINIS CAUSING BAYOUD DISEASE OF DATE PALM TREE FROM GAMBAT, DISTRICT KHAIRPUR, SINDH, PAKISTAN
}

\author{
Mirza Hussain ${ }^{1}$, Noor Jehan Ismailli² \\ ${ }^{1}$ Department of Botany, Government Girls Degree Science College, Gambat, Pakistan. \\ ${ }^{2}$ Shah Abdul Latif University, Khairpur, Pakistan.
}

\section{ART I C L E I N F O}

\section{Article history}

Received: $31^{\text {st }}$ January, 2020

Revised: $19^{\text {th }}$ March, 2020

Accepted: 22 $2^{\text {nd }}$ March, 2020

\section{Keywords}

Bayoud disease

Phoenix dactylifera $L$. Morphological characters

Fusarium oxysporum

\section{A B S T R A C T}

Among different diseases of dates, bayoud disease caused by Fusarium oxysporum $\mathrm{f}$. sp. albedinis causes serious damage to date palm throughout the world. The disease has damaged numerous date groves and can sometimes take on spectacular proportions when the disease appears in epidemic form. The disease is widespread and results in significant damage and incurs huge losses. In Pakistan, date palm is mainly cultivated in Khairpur (Sindh) and Turbat (Balochistan) districts. Date palm holds a significant position in the socio-economic development at Khairpur where several thousand peoples are associated directly or indirectly with date palm cultivation, trade and market. As no information exists about the bayoud disease in Khairpur district, therefore, in the present study, the disease was characterized on date palm trees caused by Fusarium oxysporum f. sp. albedinis at college area of Gambat, District Khairpur, Sindh, Pakistan. Samples of infected date palm trees of different varieties were collected from experimental area at the time of harvesting. The fungus was isolated, purified and identified as Fusarium oxysporum f. sp. albedinis on the basis of morphological characteristics. In conclusion, bayoud disease is an epiphytic disease for which there is no known cure at present. Only preventive measures could protect healthy date plantations from this disease.

Corresponding Author: Mirza Hussain

Email: mirzasamo512@gmail.com

(C) 2020 EScience Press. All rights reserved.

\section{INTRODUCTION}

Among different diseases of dates, bayoud disease caused by Fusarium oxysporum f. sp. albedinis causes serious damage to date palm throughout the world. The appellation bayoud has been derived from an Arabic word "abiadh" which means white due to whitening of the fronds of diseased palms. The disease was reported for the first time in 1870 from Zagora-Morocco. The disease had damaged numerous date groves by 1940 and almost all the plantations were affected after one century in Morocco and western and central Algerian Sahara (Killian and Maire, 1930; Toutain, 1965). The disease incurs huge losses and can sometimes take on spectacular proportions when the disease appears in epidemic form. The disease is widespread and results in significant damage. It has caused destruction of more than twelve million palm trees in Morocco and three million in Algeria during the last hundred years or so. It 
has damaged almost all the important varieties of date palm which were prone to the pathogen including those producing high quality and quantity fruit viz. Medjool, Deglet Nour, BouFegouss. The disease accelerated desertification and migration of farmers who were forced to leave their lands and settled in cities.

The disease continued to advance relentlessly to the east, despite prophylactic measures and regular attempts at eradication undertaken in Algeria (Djerbi et al., 1985; Dubost and Kellou, 1974). It is therefore evident that bayoud constitutes a plague to Saharan agriculture and at the present expansion rate, it will certainly pose serious problems of human, social and economic nature to other date-producing areas of the world.

The Bayoud disease is equally destructive to mature and young palms, as well as offshoots at their base (Saaidi, 1979). The disease spreads ineluctably and the palm dies when the terminal bud is affected. The palm can die at any time from several weeks to several months after the manifestation of the first symptoms. The rapid development of the symptoms depends mainly on planting conditions and on variety. A small number of disease infected roots, reddish in color, are revealed when an affected palm is uprooted. The spots are large and numerous towards the base of the stipe. As they advance towards the upper parts of the palm, the colored conducting fascicles separate and their complicated path inside the healthy tissues can be followed. Palm fronds manifesting external symptoms exhibit a reddish brown color when cut, showing highly colored conducting fascicles. There is, therefore, a continuity of vascular symptoms that exist from the roots of the palm to the tips of the palm fronds.

The observation of symptoms is necessary to recognize the bayoud, but to identify this disease with certainty, samples of affected fronds must be analyzed by a specialized laboratory. The causal organism responsible for bayoud is a microscopic fungus which belongs to the mycoflora of the soil and is named as Fusarium oxysporum f. sp. albedinis (Killian and Maire, 1930; Malençon, 1934). F. oxysporum f. sp. albedinis is preserved in the form of chlamydospores in the dead tissues of infected palm, especially in the roots which have been killed by the disease and in the soil. Contamination occurs regularly from palm to palm and more rapidly as the amount of irrigation increases. The appearance of the disease in locations far from the original infected area is caused primarily by the transport of infected offshoots or palm fragments harboring the fungus.

In Pakistan, date palm is mainly cultivated in Khairpur (Sindh) and Turbat (Balochistan) districts (Jatoi et al., 2009). Date palm holds a significant position in the socio-economic development at Khairpur where several thousand peoples are associated directly or indirectly with date palm cultivation, trade and market. As no information exists about the bayoud disease in Khairpur district, therefore, in the present study, the disease was characterized on date palm trees caused by Fusarium oxysporum f. sp. albedinis at college area of Gambat, District Khairpur, Sindh, Pakistan.

\section{MATERIALS AND METHODS}

Samples of infected date palm trees (figure 1) of different varieties were collected from experimental area at the time of harvesting with the help of sterilized forceps into polythene bags. Samples were brought to the laboratory for isolation and identification of fungal pathogens (Soomro, 1990). Czapek Dox Agar medium was used for isolation of fungal pathogens. The medium in Petri plates was inoculated with the infected parts of date trees. The inoculated Petri plates were incubated at $29^{\circ} \mathrm{C}$ for 7 days. The individual colonies were picked and placed on fresh medium in the petri plates for purification of the fungus. The fungus was identified on the basis of different keys (Cook, 1963; Gilman, 1975; Thom and Raper, 1945).

\section{RESULTS AND DISCUSSION}

On the basis of morphological characters, Fusarium oxysporum f. sp. albedinis was isolated and identified from diseased samples (Figure 2 and 3). The fungus belongs to the group Fungi Imperfecti, the Order Moniliales, the Family Tuberculariacae. The first detailed descriptions of the fungus were done by Malençon (1950a, 1950b) and Pereau-Leroy (1958). More recently the fungus was studied by Bulit et al. (1967) and Louvet et al. (1970).

The isolation, characterization, and the maintenance of culture of $F$. oxysporum $\mathrm{f}$. sp. albedinis has been the subject of numerous studies (Snyder and Hansen, 1940). Although, it is easy to obtain F. oxysporum f. sp. albedinis cultures from rachis fragments of palm leaves which exhibit vascular symptoms, it is very difficult to preserve the original type of colony. Indeed, the wild form shows greatly unstable cultural characteristics under normal conditions and rapidly produces mutants. In culture, $F$. oxysporum f. sp. albedinis forms a fine, clear and curly 
mycelium in which small orange-pink sporodochia are produced. Blue to black sclerotia sometimes are born in
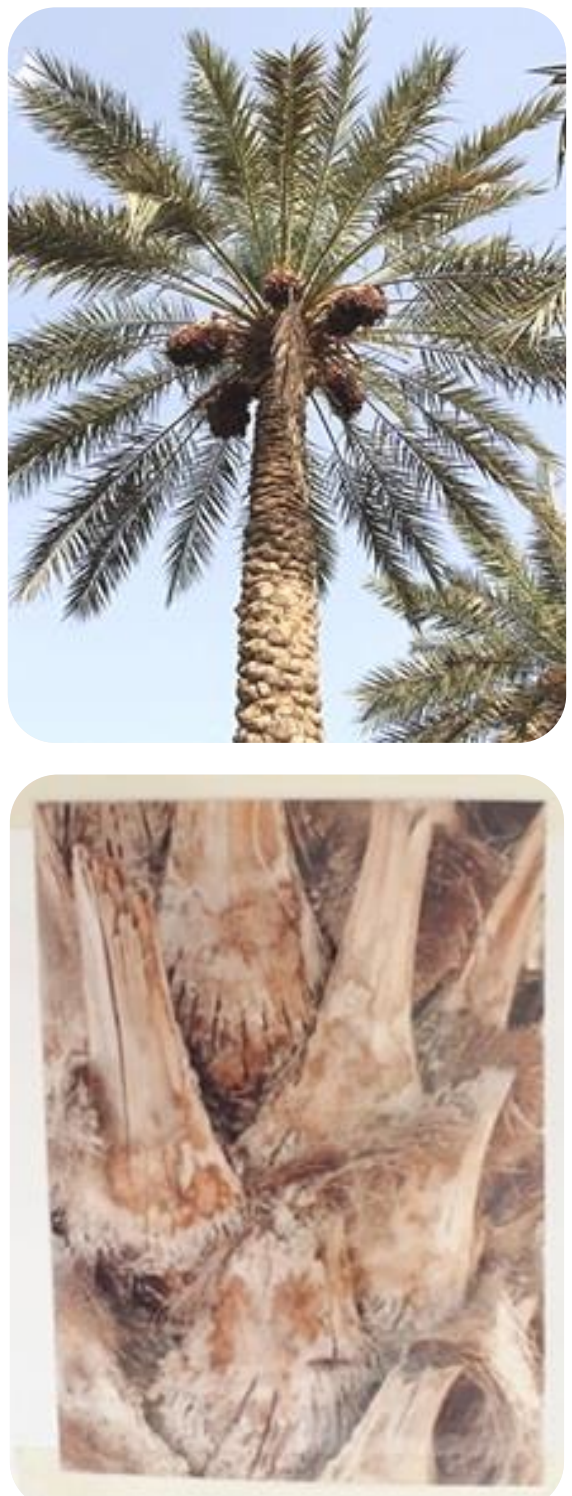

the medium. They are either dispersed in the mycelium or sometimes form groups.
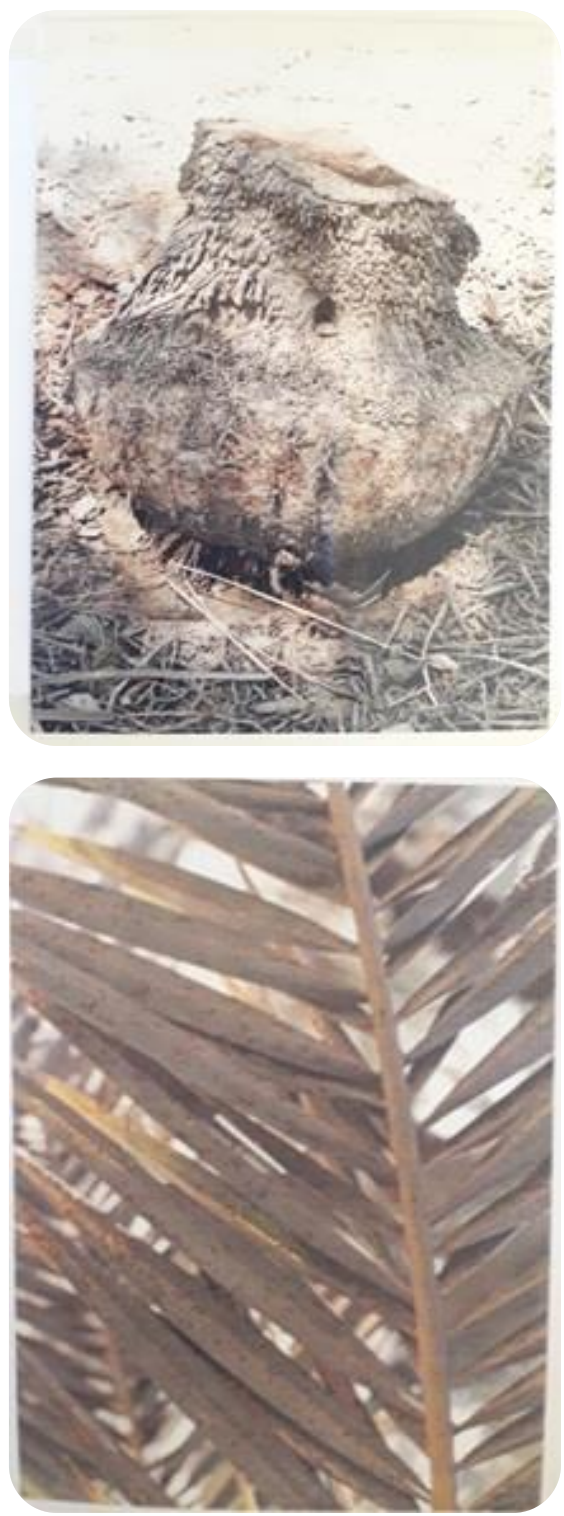

Figure 1. Bayoud infected samples.
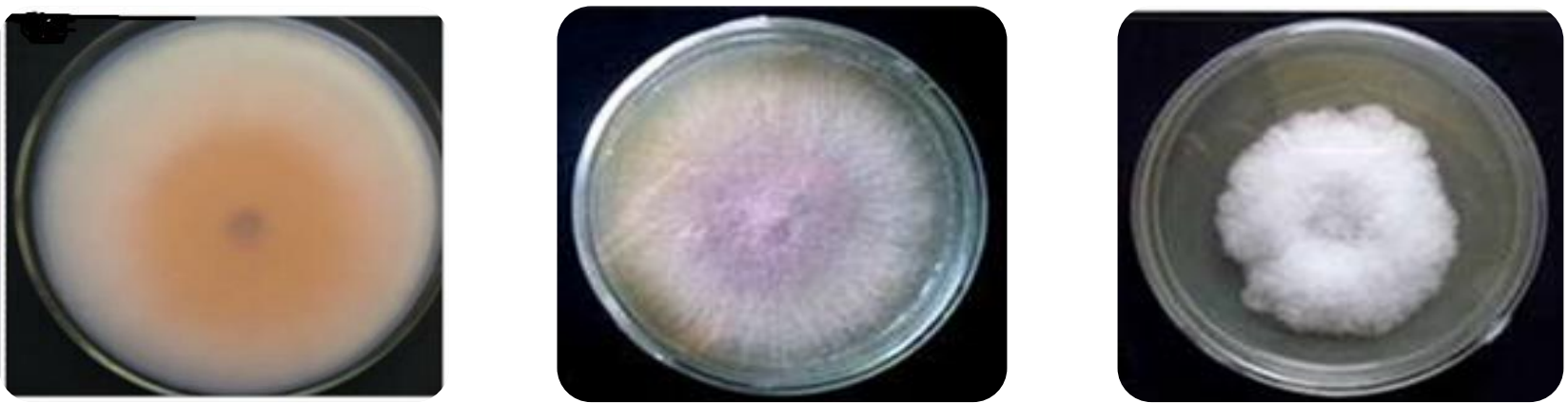

Figure 2. Mycelial growth of Fusarium oxysporum f.sp. albedinis on media plates. 

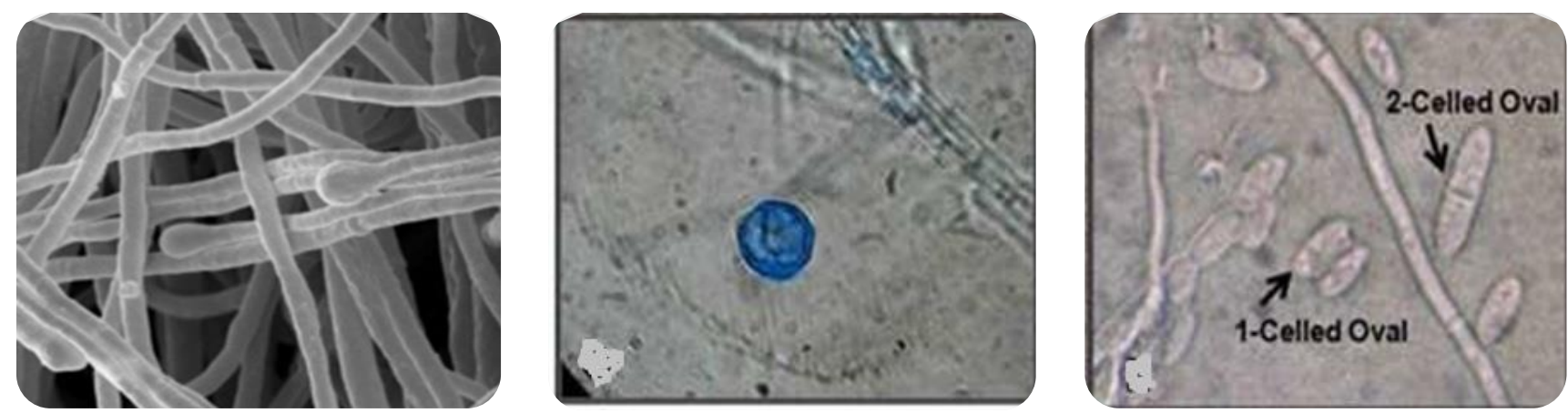

Figure 3. Conidiophores with conidia of Fusarium oxysporum f.sp. albedinis.

F. oxysporum f. sp. albedinis occurs as a septate hyaline mycelium. It is fine and uniform in young cultures, exhibiting, however, in older cultures hypertrophic cells that occur in chains; they are round, greatly resembling chlamydospores, but without thickening of the wall. Asexual multiplication occurs by microphalides swollen at the base and pointed at the tip, arising perpendicularly from the mycelium. At the apical tip of these phialides, microconidia (microphialospores) form continuously and endogenetically, each one being pushed by the next and they adhere together in the form of small moist heads. Great numbers of hyaline microconidia, varying in form and dimensions, can be found in the same culture ( 3 to $15 \times 3$ to $5 \mu \mathrm{m}$ ). In young cultures they are globulous, while in the older cultures they are more elongated. Microconidia are often unicellular, sometimes bicellular but rarely have two septa. Macrophialides, larger than microphialides, group together to form sporodochia and more rarely pionnotes. In culture, F. oxysporum f. sp. albedinis also produces a few macroconidia with pediform base and short, pointed tips; most have three septa, though some have four or five and measure 20 to $30 \times 3$ to $5 \mu \mathrm{m}$.

In older cultures, or in an agar medium covered over with earth, F. oxysporum f. sp. albedinis forms chlamydospores that are uniform and globulous, with a smooth thick wall varying from 6 to $20 \mu$ (Baysal et al., 2010). They may be either intercalary or terminal and are isolated or grouped in two or four in short chains. They are formed either on the mycelium or from macroconidia. Sclerotia are dark blue-black, measure about $1 \mathrm{~mm}$ in diameter and occur rarely (Sedra et al., 1985).

The growth of the fungus begins at $7^{\circ} \mathrm{C}$, remains slow until $12{ }^{\circ} \mathrm{C}$, becomes more rapid between 21 and $27.5^{\circ} \mathrm{C}$ and stops at $37^{\circ} \mathrm{C}$ (Shabani and Kumar, 2013; Shabani et al., 2014) and the best mycelial growth occurs at $28{ }^{\circ} \mathrm{C}$
(Bounaga, 1975).

Like all vascular organisms, F. oxysporum f. sp. albedinis survives in the form of chlamydospores in the dead tissues of infected palm trees, especially in the roots of trees killed by the fungus. The fungus is found at a depth varying from 5 to $30 \mathrm{~cm}$, and sometimes deeper. It can be preserved for longer periods (eight years or more) even after the death of palm trees. If chlamydospores receive sufficient nutrients, the spores germinate and invade new healthy roots and enter the vascular tissues as a parasite (de La Perrière and Benkhalifa, 1991).

In conclusion, bayoud disease is an epiphytic disease for which there is no known cure at present. Only preventive measures could protect healthy date plantations from this disease.

\section{CONFLICT OF INTEREST}

The authors declare no conflict of interest.

\section{AUTHORS' CONTRIBUTION}

MH and NJI designed and executed the study. Both the authors prepared and edited the manuscript.

\section{REFERENCES}

Baysal, Ö., Siragusa, M., Gümrükcü, E., Zengin, S., Carimi, F., Sajeva, M., Da Silva, J.A.T., 2010. Molecular Characterization of Fusarium oxysporum f. melongenae by ISSR and RAPD Markers on Eggplant. Biochememical Genetics 48, 524-537.

Bounaga, N., 1975. Germination de microconidies et macroconidies de Fusarium oxysporum f. sp. albedinis. Bulletin de la Société d'Histoire Naturelle de l'Afrique du Nord. 66, 39-44.

Bulit, J., Louvet, J., Bouhot, D., Toutain, G., 1967. Recherches sur les fusarioses. I. Travaux sur le bayoud, fusariose vasculaire du palmier dattier en Afrique du Nord. Annales des Epiphyties 18, 213239.

Cook, W.B., 1963. A laboratory guide to fungi of polluted 
water, sewage and sewage system. Cincinnati Public Health Services.

de La Perrière, R.A.B., Benkhalifa, A., 1991. Progression de la fusariose du palmier dattier en Algérie. Science et Changements Planétaires/Sécheresse 2, 119-128.

Djerbi, M., El-Ghorfi, A., El-Idrissi, A., 1985. Etude du comportement du henné Lawsonia inermis et de la luzerne Medicago sativa et quelques espfces de palmacées vis-à-vis du Fusarium oxysporum f. sp. albedinis, agent causal du bayoudh. Annales de l'Institute National de la Recherche Agronomique de Tunisie 58, 1-11.

Dubost, D., Kellou, R., 1974. Organisation de la recherche et de la lutte contre le bayoud en Algérie. Bulletin d'Agronomie Saharienne 1, 5-13.

Gilman, J.C., 1975. A manual of soil fungi. IOWA State College Press, USA.

Jatoi, M.A., Markhand, Z., Solangi, N., 2009. Dates in Sindh: facts and figures, Proceedings of the International Dates Seminar, pp. 59-70.

Killian, C., Maire, R., 1930. Le bayoud, maladie du dattier. Bulletin de la Société d'Histoire Naturelle de l'Afrique du Nord 21, 89-101.

Louvet, J., Bulit, J., Toutain, G., Rieuf, P., 1970. Le bayoud, fusariose vasculaire $\mathrm{du}$ palmier dattier symptomes et nature de la maladie moyens de lutte. Al-Awamia 35, 16l-162.

Malençon, G., 1934. Nouvelles observations concernant l'étiologie $\mathrm{du}$ bayoud. Comptes Rendus de l'Académie des Sciences 19, 1259-1262.

Malençon, G., 1950a. La diffusion et l'épidémiologie de la maladie fusarienne du palmier dattier en Afrique du Nord. Review of Applied Mycology 30, 154-155.

Malençon, G., 1950b. Le bayoud, maladie fusarienne du palmier dattier en Afrique du Nord. Fruits
d'Outre-mer 5, 279-289.

Pereau-Leroy, P., 1958. Le palmier dattier au Maroc. Royaume du Maroc, Ministere de l'Agriculture, Institut Français de Recherches Fruitières Outremer, p. 142.

Saaidi, M., 1979. Contribution à la lutte contre le bayoud, fusariose vasculaire du palmier dattier, Ph.D. Thesis, University of Dijon, France.

Sedra, M.H., Djerbi, M., Chadli, F., Assari, K., 1985. Mise au point d'une méthode rapide et précise d'identification in vitro du Fusarium oxysporum f. sp. albenidis, agent causal du Bayoud. Annales de l'Institut National de la Recherche Agronomique de Tunisie 58, 1-12.

Shabani, F., Kumar, L., 2013. Risk levels of invasive Fusarium oxysporum f. sp. albedinis in areas suitable for date palm (Phoenix dactylifera) cultivation under various climate change projections. Plos One 8.

Shabani, F., Kumar, L., Esmaeili, A., 2014. Future distributions of Fusarium oxysporum f. sp. albedinis in European, Middle Eastern and North African agricultural regions under climate change. Agriculture, Ecosystems \& Environment 197, 96105.

Snyder, C.W., Hansen, H.N., 1940. The species concept in fusarium. American Journal of Botany 27, 64-67.

Soomro, I.A., 1990. Isolation and identification of dermatophytey and other keratinophilic fungi from the soil of Shah Abdul Latif University Khairpur Sindh Pakistan. Scientific Khyber 3, 175182.

Thom, C., Raper, K.B., 1945. A manual of the Aspergilli. The William and Wikins Co. Baltimore.

Toutain, G., 1965. Note sur l'épidémiologie du bayoud en Afrique du Nord. Al-Awamia 15, 37-45. 